\title{
EFFECT OF ROOM TEMPERATURE ON SEROLOGIC TESTS FOR SYPHILIS*
}

\author{
BY \\ HILFRED N. BOSSAK, AD HARRIS, AND SIDNEY OLANSKY \\ From the Venereal Disease Research Laboratory, Venereal Disease Program, \\ Division of Special Health Services, United States Public Health Service, Chamblee, Ga.
}

The maintenance of uniform levels of performance in serological tests for syphilis is dependent upon many factors. Three of the most important are :

(1) strict adherence to an accepted, published technique ;

(2) the use of standardized reagents ;

(3) the temperature at which the tests are performed.

The effects of temperature on the results obtained in the older serological tests for syphilis employing lipoidal antigens is well known. In fact, the differences in test results obtained when certain tests were performed at different temperatures served not only as the basis for attempted differentiation of syphilitic from so-called biologic false positive reactions (Kahn, 1940), but also for determining the relative specificity of different lots of lipoidal antigens (Kline and Suessenguth, 1946).

Other workers have shown that test sensitivity is affected not only by the temperature at which the antigen-saline emulsions are prepared (Cannefax and others, 1953) but also by the temperature of the glassware and reagents (Fugazzotto, 1953). Exposure of blood or serum samples to temperatures above those employed for refrigeration increases the rate of haemolysis on the one hand and depresses the serological titre on the other, in proportion to the duration of exposure and the elevation of temperature. Most of the widely used serological tests for syphilis, with the exception of those performed at 4 to $6^{\circ} \mathrm{C}$. or $37^{\circ} \mathrm{C}$., are carried out at so-called " room temperature", but this term becomes meaningless when the wide seasonal variations in laboratory temperatures which occur nationally and internationally are considered.

In order to show the effect of these temperature

\footnotetext{
*Received for publication November 29, 1954.
}

variations on serological tests for syphilis, other than those employing refrigerator temperature or incubation at $37^{\circ} \mathrm{C}$., and to determine optimal temperature limits for performance of these tests, comparative tests were performed using six selected techniques at temperatures ranging from 15 to $40^{\circ} \mathrm{C}$. $\left(60\right.$ to $100^{\circ} \mathrm{F}$.). The purpose of this report is to present the results obtained when both whole serum and serum diluted with saline were tested with the Kahn test employing lipoidal antigen and the Kline, Mazzini, Rein-Bossak, and VDRL slide and tube tests using cardiolipin-lecithin antigens, between these temperature limits.

\section{Method}

Sera.-Individual pools of serum of varying degrees of reactivity were collected, Seitz-filtered, separated into aliquots, and stored without preservative at $-20^{\circ} \mathrm{C}$. until tested. One set of aliquots was removed from the deep-freeze cabinet on each testing day, thawed, mixed thoroughly, and heated at $56^{\circ} \mathrm{C}$. for $30 \mathrm{~min}$. before testing. To reduce technical differences to a minimum, testing at any given temperature was repeated on three separate testing days with aliquots of the same group of sera, although several groups of different sera were employed during the study. Dilutions of dehydrated serum in saline also were included each time tests were performed.

Performance of Tests.-All the techniques used were performed exactly as described in the "Manual of Serologic Tests for Syphilis, 1949 ". Glassware, reagents, and equipment were allowed to reach the temperature at which the tests were being investigated before antigen emulsions were prepared and the tests performed.

Antigens for the tests were prepared and standardized at the Venereal Disease Research Laboratory, with the exception of one lot of Kahn antigen, obtained from the University Hospital, Ann Arbor, Mich., and one lot of Kline antigen, which was purchased from the LaMotte Chemical Company, Baltimore, Md. 


\section{Results}

The results obtained with the tests performed in this study are listed in Tables I, II, and III. Table I shows the findings obtained in initial testing at two extremes of temperature; 15 and $40^{\circ} \mathrm{C}$., with $25^{\circ} \mathrm{C}$. included as an average representative room temperature. Table II lists test results obtained within the narrower temperature limits of 21 , 27 , and $32^{\circ} \mathrm{C}$. Table III gives comparative results obtained at 23 and $29^{\circ} \mathrm{C}$.

\section{Discussion}

Slide Flocculation Tests.-Results obtained with four slide flocculation tests, employing cardiolipinlecithin antigens at various temperatures, are listed in Tables I, II, and III. As shown in Table I, all four tests showed marked differences in reactivity when performed at 15 and $40^{\circ} \mathrm{C}$. Out of a total of sixty specimens tested, only four $3+$ or $4+$ reactions were obtained with the Kline test, none with the Mazzini, and six with the Rein-Bossak test, when tests were performed at $15^{\circ} \mathrm{C}$. By contrast, maximal $(4+)$ reactions were obtained on all sixty specimens with each of the three tests when the room temperature was raised to $40^{\circ} \mathrm{C}$.
Only two reactive results were obtained with the VDRL slide test at $15^{\circ} \mathrm{C}$; 25 of the remaining test results were weakly reactive and 33 were nonreactive. As the room temperature was increased to $25^{\circ} \mathrm{C}$., non-reactive findings were reduced to six and reactive findings increased from two to 28 . At $40^{\circ} \mathrm{C}$., no non-reactive or weakly reactive results were obtained.

Quantitative testing was likewise affected by temperature extremes. End-point titres of some sera with the Kline test increased from less than 20 to 40 dils (Harris, 1947), with the Mazzini test from less than 20 to 80 dils, and with the Rein-Bossak from 40 to 160 dils. Quantitative tests performed with the VDRL showed increases of at least a two-fold dilution when the room temperature was increased from 15 to $25^{\circ} \mathrm{C}$.

In order to establish temperature limits within which tests were minimally affected by room temperature, additional testing was performed within narrower temperature limits of 21 to $32^{\circ} \mathrm{C}$. (Table II). A slight increase in reactivity was noted in the results obtained with the Kline and ReinBossak tests when the operating temperature was increased from 27 to $32^{\circ} \mathrm{C}$, and all four slide

TABLE I

COMPARATIVE RESULTS OBTAINED IN TESTS FOR SYPHIL.IS PERFORMED AT 15, 25 , AND $40^{\circ} \mathrm{C}$.

\begin{tabular}{|c|c|c|c|c|c|c|c|c|c|c|c|c|c|c|c|c|c|c|c|c|c|}
\hline \multirow{2}{*}{$\frac{\text { Test ... }}{\text { Temperature }}$} & \multirow{2}{*}{\multicolumn{2}{|c|}{$\therefore \quad \ldots$}} & \multirow{2}{*}{$\cdots$} & \multicolumn{3}{|c|}{ Kahn Standard* } & \multicolumn{3}{|c|}{ Kline Standard } & \multicolumn{3}{|c|}{ Mazzini } & \multicolumn{3}{|c|}{ Rein-Bossak } & \multicolumn{3}{|c|}{ VDRL Slide } & \multicolumn{3}{|c|}{ VDRL Tube. } \\
\hline & & & & $15^{\circ} \mathrm{C}$ & $25^{\circ} \mathrm{C}$. & $40^{\circ} \mathrm{C}$ & $15^{\circ} \mathrm{C}$. & $25^{\circ} \mathrm{C}$ & $40^{\circ} \mathrm{C}$ & $15^{\circ} \mathrm{C}$ & $25^{\circ} \mathrm{C}$ & $40^{\circ} \mathrm{C}$ & $15^{\circ} \mathrm{C}$ & $25^{\circ} \mathrm{C}$. & $40^{\circ} \mathrm{C}$. & $15^{\circ} \mathrm{C}$ & $.25^{\circ} \mathrm{C}$ & $40^{\circ} \mathrm{C}$ & $15^{\circ} \mathrm{C}$ & $25^{\circ} \mathrm{C}$ & $40^{\circ} \mathrm{C}$ \\
\hline \multirow{8}{*}{ Results } & \multicolumn{3}{|c|}{$4+$} & 24 & 24 & 1 & 0 & 19 & 60 & 0 & 38 & 60 & 0 & 22 & 60 & - & - & - & - & - & - \\
\hline & \multicolumn{3}{|c|}{$3+$} & 18 & 22 & 8 & 4 & 9 & 0 & 0 & 6 & 0 & 6 & 10 & 0 & - & 一 & - & - & - & - \\
\hline & \multicolumn{3}{|c|}{$2+$} & 16 & 14 & 5 & 18 & 16 & 0 & 0 & 12 & 0 & 10 & 13 & 0 & - & - & - & - & - & - \\
\hline & \multicolumn{3}{|c|}{$1+$} & 2 & 0 & 7 & 8 & 14 & 0 & 0 & 4 & 0 & 14 & 15 & 0 & - & - & - & - & - & - \\
\hline & \multicolumn{3}{|c|}{ \pm} & 0 & 0 & 5 & 21 & 2 & 0 & 0 & 0 & 0 & 13 & 0 & 0 & - & - & - & - & - & - \\
\hline & \multirow{3}{*}{\multicolumn{3}{|c|}{$\begin{array}{l}\text { Non-reactive } \\
\text { Weakly reactive } \\
\text { Reactive }\end{array}$}} & 0 & 0 & 34 & 9 & 0 & 0 & 60 & 0 & 0 & 17 & 0 & 0 & 33 & 6 & 0 & 0 & 0 & 2 \\
\hline & & & & - & 一 & - & - & - & - & - & - & - & - & - & - & 25 & 26 & 0 & - & - & - \\
\hline & & & & - & - & - & - & - & 一 & - & - & - & - & - & - & 2 & 28 & 60 & 60 & 60 & 58 \\
\hline \multirow[t]{2}{*}{ Totals } & 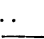 & $\ldots$ & . & 60 & 60 & 60 & 60 & 60 & 60 & 60 & 60 & 60 & 60 & 60 & 60 & 60 & 60 & 60 & 60 & 60 & 60 \\
\hline & \multicolumn{3}{|c|}{$\begin{array}{l}\text { Non-reactive at } \\
1: 20\end{array}$} & 0 & 0 & 6 & 0 & 0 & 0 & 0 & 0 & 0 & 0 & 0 & 0 & 0 & 0 & 0 & 0 & 0 & 0 \\
\hline \multirow{6}{*}{$\begin{array}{l}\text { Quanti- } \\
\text { tative } \\
\text { Tests } \\
\text { (dils) }\end{array}$} & \multicolumn{3}{|c|}{$<20$} & 0 & 0 & 0 & 2 & 0 & 0 & 6 & 0 & 0 & 0 & 0 & 0 & 0 & 0 & 0 & 0 & 0 & 0 \\
\hline & \multicolumn{3}{|c|}{20} & 6 & 6 & 0 & 2 & 4 & 2 & 0 & 0 & 0 & 0 & 0 & 0 & 4 & 0 & 0 & 0 & 0 & 0 \\
\hline & \multicolumn{3}{|c|}{40} & 0 & 0 & 0 & 2 & 2 & 4 & 0 & 6 & 0 & 6 & 2 & 0 & 2 & 6 & 5 & 0 & 0 & 0 \\
\hline & \multicolumn{3}{|c|}{80} & 0 & 0 & 0 & 0 & 0 & 0 & 0 & 0 & 6 & 0 & 4 & 4 & 0 & 0 & 1 & 1 & 0 & 0 \\
\hline & \multicolumn{3}{|c|}{160} & 0 & 0 & 0 & 0 & 0 & 0 & 0 & 0 & 0 & 0 & 0 & 2 & 0 & 0 & 0 & 5 & 4 & 5 \\
\hline & \multicolumn{3}{|c|}{320} & 0 & 0 & 0 & 0 & 0 & 0 & 0 & 0 & 0 & 0 & 0 & 0 & 0 & 0 & 0 & 0 & 2 & 1 \\
\hline Totals. & . & . & $\ldots$ & 6 & 6 & 6 & 6 & 6 & 6 & 6 & 6 & 6 & 6 & 6 & 6 & 6 & 6 & 6 & 6 & 6 & 6 \\
\hline
\end{tabular}


TABLE II

COMPARATIN'E RESULTS OBTAINED IN TESTS FOR SYPHILIS PERFORMED AT 21,27 , AND $32^{\circ} \mathrm{C}$.

\begin{tabular}{|c|c|c|c|c|c|c|c|c|c|c|c|c|c|c|c|c|c|c|c|c|c|}
\hline \multirow{2}{*}{\multicolumn{2}{|c|}{$\frac{\text { Test } \quad . .}{\text { Temperature }}$}} & \multirow{2}{*}{. } & \multirow{2}{*}{$\cdots$} & \multicolumn{3}{|c|}{ Kahn Standard* } & \multicolumn{3}{|c|}{ Kline Standard } & \multicolumn{3}{|c|}{ Mazzini } & \multicolumn{3}{|c|}{ Rein-Bossak } & \multicolumn{3}{|c|}{ VDRL Slide } & \multicolumn{3}{|c|}{ VDRL Tube } \\
\hline & & & & $21^{\circ} \mathrm{C}$ & $27^{\circ} \mathrm{C}$ & $32^{\circ} \mathrm{C}$ & $21^{\circ} \mathrm{C}$. & $27^{\circ} \mathrm{C}$ & $32^{\circ} \mathrm{C}$. & $21^{\circ} \mathrm{C}$ & $27^{\circ} \mathrm{C}$ & $32^{\circ} \mathrm{C}$ & $21^{\circ} \mathrm{C}$ & $27^{\circ} \mathrm{C}$ & $32^{\circ} \mathrm{C}$ & $21^{\circ} \mathrm{C}$ & $27^{\circ} \mathrm{C}$ & $.32^{\circ} \mathrm{C}$ & $21^{\circ} \mathrm{C}$. & $27^{\circ} \mathrm{C}$. & $32^{\circ} \mathrm{C}$. \\
\hline \multirow{8}{*}{ Results } & & \multicolumn{2}{|c|}{$4+$} & 10 & 12 & 8 & 0 & 8 & 12 & 0 & 14 & 15 & 6 & 14 & 19 & - & - & - & - & - & - \\
\hline & & \multicolumn{2}{|c|}{$3+$} & 15 & 18 & 10 & 7 & 10 & 6 & 6 & 4 & 3 & 8 & 7 & 4 & - & - & - & - & - & - \\
\hline & & \multicolumn{2}{|c|}{$2+$} & 15 & 11 & 15 & 10 & 4 & 4 & 8 & 4 & 5 & 7 & 3 & 2 & - & - & 一 & - & - & - \\
\hline & & \multicolumn{2}{|c|}{$1+$} & 6 & 7 & 13 & 5 & 3 & 3 & 7 & 3 & 3 & 3 & 0 & 1 & - & - & - & - & - & - \\
\hline & & \multicolumn{2}{|c|}{ \pm} & 1 & 0 & 1 & 3 & 2 & 2 & 0 & 0 & 0 & 1 & 2 & 1 & - & - & - & - & - & - \\
\hline & \multicolumn{3}{|c|}{ Non-reactive } & 13 & 12 & 13 & 5 & 3 & 3 & 9 & 5 & 4 & 5 & 4 & 3 & 19 & 8 & 9 & 6 & 5 & 6 \\
\hline & \multicolumn{3}{|c|}{ Weakly reactive } & - & - & - & - & - & - & 一 & - & - & - & - & - & 6 & 6 & 8 & 0 & 0 & 0 \\
\hline & \multicolumn{3}{|c|}{ Reactive } & - & - & - & - & - & - & - & - & - & - & 一 & - & 5 & 16 & 13 & 24 & 25 & 24 \\
\hline Totals & .. & $\cdots$ & . & 60 & 60 & 60 & 30 & 30 & 30 & 30 & 30 & 30 & 30 & 30 & 30 & 30 & 30 & 30 & 30 & 30 & 30 \\
\hline \multirow{3}{*}{$\begin{array}{l}\text { Quanti- } \\
\text { tative } \\
\text { Tests } \\
\text { (dils) }\end{array}$} & \multicolumn{3}{|c|}{10} & 6 & 6 & 6 & 3 & 2 & 1 & 3 & 2 & 2 & 0 & 0 & 0 & 0 & 0 & 0 & 0 & 0 & 0 \\
\hline & \multicolumn{3}{|c|}{20} & 0 & 0 & 0 & 0 & 1 & 2 & 0 & 1 & 1 & 3 & 2 & 0 & 3 & 3 & 3 & 0 & 0 & 1 \\
\hline & \multicolumn{3}{|c|}{40} & 0 & 0 & 0 & 0 & 0 & 0 & 0 & 0 & 0 & 0 & 1 & 3 & 0 & 0 & 0 & 3 & 3 & 2 \\
\hline Totals & $\cdots$ & . & $\ldots$ & 6 & 6 & 6 & 3 & 3 & 3 & 3 & 3 & 3 & 3 & 3 & 3 & 3 & 3 & 3 & 3 & 3 & 3 \\
\hline
\end{tabular}

*Antigen prepared and standardized at the Venereal Disease Research Laboratory.

TABLE III

COMPARATIVE RESULTS OBTAINED IN TESTS FOR SYPHILIS PERFORMED AT 23 AND $29^{\circ} \mathrm{C}$.

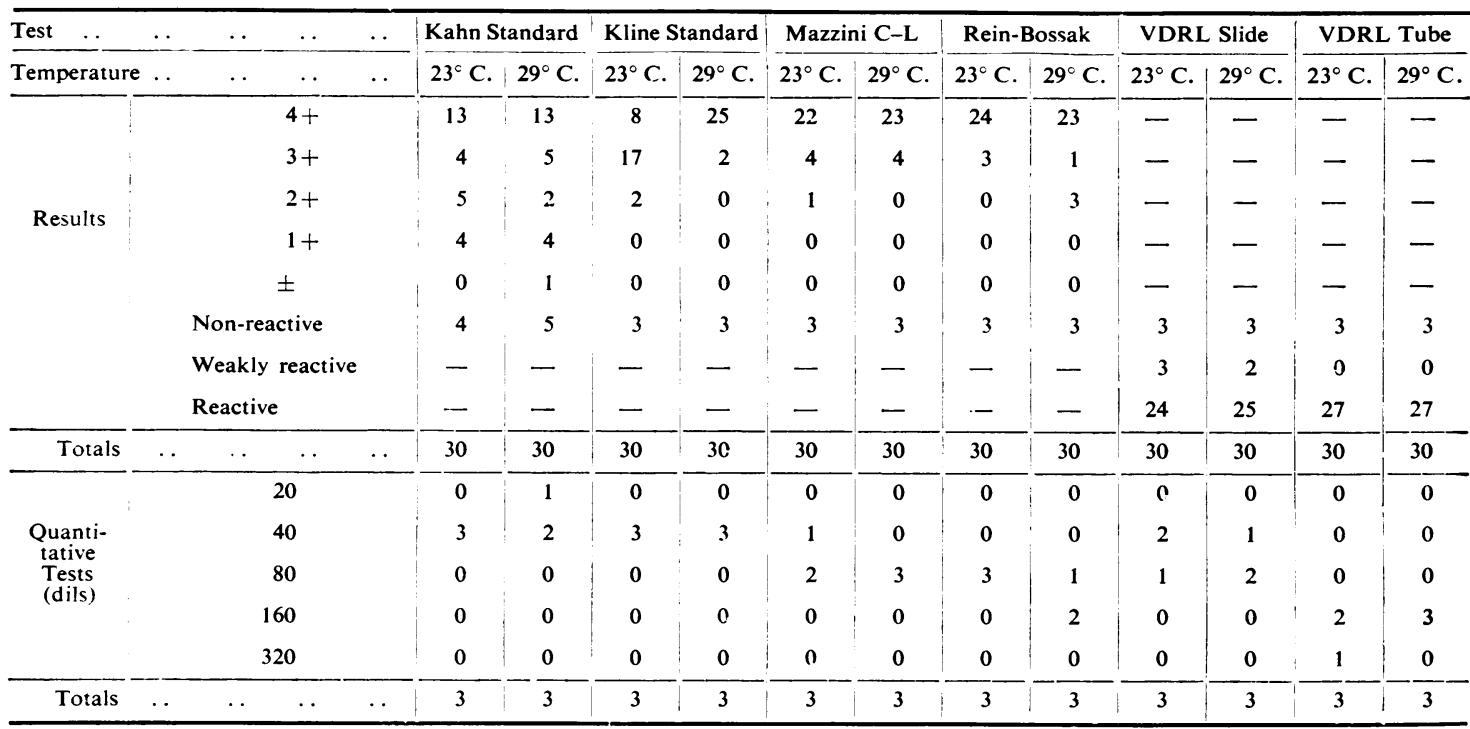

flocculation tests were definitely less reactive when the room temperature was lowered from 27 to $21^{\circ} \mathrm{C}$.

Since it was desirable that optimal operating temperatures be established for as many of the serological tests as possible, the lower temperature limit was raised to $23^{\circ} \mathrm{C}$. and the upper limit lowered from 32 to $29^{\circ} \mathrm{C}$. Final comparative testing was accomplished within these temperature limits (Table III). No significant difference was observed in the results obtained with either of the four techniques, when qualitative or quantitative tests were performed within the temperature limits indicated, and it would therefore appear that the 
effect of temperature variants on the four slide flocculation tests employed in this study can be reduced to a minimum if testing is carried out at room temperatures between 23 and $29^{\circ} \mathrm{C}$.

VDRL Tube Test.-As indicated in all three Tables, no significant variation in reactivity was noted in either qualitative or quantitative results when tests were performed at any of the listed temperatures ranging from 15 to $40^{\circ} \mathrm{C}$.

Kahn Test.-The test results listed in Table I were obtained with a lot of Kahn Standard antigen obtained from the University Hospital, Ann Arbor, Mich. Little difference in reactivity was noted when the Standard Kahn test was performed at 15 or $25^{\circ} \mathrm{C}$., although non-reactive results were quite turbid and difficult to read. A marked drop in reactivity was noted, however, at $40^{\circ} \mathrm{C}$.

Whereas no non-reactive results were obtained in tests on individual sera at 15 and $25^{\circ} \mathrm{C}$., 34 of the same sera dropped to negativity when tested at $40^{\circ} \mathrm{C}$. Similar results were observed in quantitative testing. Six separate testings of serum diluted in saline produced identical end-point titres of 20 dils when tests were performed at either 15 or $25^{\circ} \mathrm{C}$. In all six instances, however, completely non-reactive results were obtained at the same dilution at $40^{\circ} \mathrm{C}$. The test results listed in Table II were obtained with a lot of Kahn Standard antigen prepared and standardized at the Venereal Disease Research Laboratory. Little difference was noted in the results obtained in either qualitative or quantitative tests performed at temperatures between 21 and $32^{\circ} \mathrm{C}$.

\section{Summary and Conclusions}

The reactivity levels of all of the tests included in this study, with one exception, were affected in varying degrees by marked changes in the room temperature at which the testing was carried out.

The Kline Standard, VDRL slide, Mazzini, and Rein-Bossak tests, employing cardiolipin-lecithin antigens, showed progressive decrease in reactivity in qualitative and quantitative testing at room temperatures below $23^{\circ} \mathrm{C}$. and became increasingly reactive at temperatures above $32^{\circ} \mathrm{C}$.

The VDRL tube test showed no significant variation in reactivity when performed at room. temperatures between 15 and $40^{\circ} \mathrm{C}$.

Qualitative and quantitative Kahn test reactivity was significantly lowered when testing was performed at temperatures above $32^{\circ} \mathrm{C}$. No appreciable difference in reactivity was noted when tests were performed at room temperatures between 15 and $32^{\circ} \mathrm{C}$.

The effect of room temperature variants on serological test reactivity was reduced to a minimum when the tests employed in this study were performed between 23 and $29^{\circ} \mathrm{C}$. ( 73 to $84^{\circ} \mathrm{F}$.).

\section{REFERENCES}

Cannefax, G. R., Beyer, H. R., and Johnwick, E. B. (1953). Amer. J. Syph., 37, 348.

Fugazzotto, P. (1953). Publ. Hlth Rep. (Wash.), 68, 304.

Harris, A. (1947). J. vener. Dis. Inform., 28, 249.

Kahn, R. L. (1940). Arch. Derm. Syph. (Chicago), 41, 817.

Kline, B. S., and Suessenguth, H. (1946). Amer. J. clin. Path., 16, 391.

U.S. Public Health Service (1949). " Manual of Serologic Tests for Syphilis ", J. vener. Dis. Inform., Suppl. 22. 